\title{
Does Agriculture Matter for Environmental Kuznets Curve in Russia: Evidence from the ARDL Bounds Tests Approach
}

\author{
Dmitry Burakov \\ Department of Banks, Monetary Circulation and Credit, Moscow State Institute of International Relations, \\ (MGIMO-University), Russia \\ Department of Financial Markets \& Banks, Financial University under the Government of Russian Federation, \\ Moscow, Russia
}

\begin{abstract}
This study explores the relationship between carbon dioxide emissions and their main determinants, which include real income and energy consumption in Russia, employing data for the period 1990-2016. The hypothesis of agriculture being an important determinant of environmental quality in Russia is also tested. For estimating the short-run and long-run relationships the ARDL bounds test approach is employed in this study. The results are consistent with the Environmental Kuznets Curve (EKC) hypothesis and show that the real income and energy consumption have a statistically significant positive impact on the carbon emission and its square has a significant negative effect on the carbon emissions both in the short-run and long-run. Agricultural sector is found to be a relatively important statistically significant determinant of carbon emission in Russia as well. The pairwise Granger causality test also reveals unidirectional causality running from agriculture to the carbon emissions.
\end{abstract}

\section{Keywords}

Environmental Kuznets curve, agriculture, economic growth, $\mathrm{CO}_{2}$ emission.

Burakov, D. (2019) "Does Agriculture Matter for Environmental Kuznets Curve in Russia: Evidence from the ARDL Bounds Tests Approach", AGRIS on-line Papers in Economics and Informatics, Vol. 11, No. 3, pp. 23-34. ISSN 1804-1930. DOI 10.7160/aol.2019.110303.

\section{Introduction}

\section{Environmental pollution: problem statement}

Environmental pollution is one of the main areas of research in the field of the environmental economics. The problems of climate changes, global warming and worsening quality of environment, brought to life by an increased industrial output, are related to an increased greenhouse gases emission, which include carbon dioxide $\left(\mathrm{CO}_{2}\right)$, methane $\left(\mathrm{CH}_{4}\right)$ and nitrous oxide $\left(\mathrm{N}_{2} \mathrm{O}\right)$ as well. According to the estimates of the World Bank (2018), agricultural sector is responsible for $15 \%-35 \%$ of the global greenhouse gases emissions, depending on whether it is related with deforestation or not. On the other hand, agricultural sector remains on the main fields in the national economies, which helps to maintain the national security, at least in part of the food security, not to mention the function of meeting the basic demand of the households.

Given the above, the importance of agricultural sector for the national economy, as well as its role in the environmental pollution under certain assumptions is rather hard to overestimate. Concerning the studied country, one should notice, that Russia takes the $4^{\text {th }}$ place among other countries, contributing in the world $\mathrm{CO}_{2}$ emissions, after China, the United States of America and India in total kilotons $(\mathrm{kt})$. Yet, in terms of kilogram $(\mathrm{kg})$ of $\mathrm{CO}_{2}$ emission per GDP, measured in 2010 US dollars, in 2014, according to the World Bank data (2018), Russia with $0.999 \mathrm{~kg}$ outplaced the US with $0.324 \mathrm{~kg}$. According to the world tendency among developed countries, $\mathrm{CO}_{2}$ steadily declines. However, in Russia $\mathrm{CO}_{2}$ emissions continue to rise. Since 1998 minimum, the level of $\mathrm{CO}_{2}$ emissions has increased on $14 \%$ up to 2014 . If the GDP is taken into account, the picture changes: $\mathrm{CO}_{2}$ emissions, measured as $\mathrm{kg}$ per 2010 US dollars of GDP, decline from 1.839 in 1998 to 0.999 in 2014. This tendency is the results of using more friendly-environmental technologies in some sectors of the national economy. However, 
due to rising share of agriculture in Russian GDP from $3.9 \%$ in 2011 up to $5 \%$ in 2017 , the question of potential increase in $\mathrm{CO}_{2}$ emissions arises, which advocates the relevance of this study, given the potential threat of increasing $\mathrm{CO}_{2}$ emissions.

\section{Literature review}

The problem of environmental pollution has already received much attention in the literature. Most empirical studies are based on the theoretical hypothesis of the environmental Kuznets curve (EKC). The EKC framework underlines the importance of energy consumption in producing the national GDP and assumes the existence of an inverted U-shaped relationship between environmental degradation and real income per capita. As national income rises, environmental pollution initially is rising as well. However, achieving a certain threshold in national economic development, the level of emissions declines and pollution is assumed to decrease (Kuznets, 1955).

The initial wave of empirical studies tested the EKC hypothesis in narrow sense, aiming to describe and explain environmental pollution solely by economic factors, including different proxies for economic growth (Grossman and Krueger, 1995; Heil and Selden, 1999; Akbostanci et al., 2009; Poudel et al., 2009; Narayan and Narayan, 2010; Onafowora and Owoye, 2014).

The second wave of the studies is different in a more deeply oriented approach, taking into consideration the structural issue: these studies seek for additional or structural factors that may amplify or accelerate the environment pollution process. Some studies accentuate importance of energy consumption as a leading factor of environmental degradation (Soytas and Sari, 2009; Acaravci and Ozturk, 2010; Pao and Tsai, 2010; Alam et al., 2012; Dagher and Yacoubian, 2012; Saboori and Sulaiman, 2013; Shahbaz et al., 2015; Benavides et al., 2017; Shahbaz et al., 2017). These studies bring evidence in favor of energyinduced EKC both for developed and developing countries, yet in some cases the results are heterogeneous due to differences in econometric techniques used.

The third wave of empirical research is aimed at mitigating the omitted variables bias and include various additional proxies for incorporation of changes in international environment and globalization processes. Recently, the importance of changes in energy prices and terms of international trade gain attention in testing the EKC. The issue of trade liberalization and globalization has led to a rise in international trade, which spurred the total output, leading to a rise in environmental pollution (Halicioglu, 2009; Rabi et al., 2015; Halicioglu and Ketenci, 2016; El-Aasar and Hanafy, 2018). An increased volatility of energy prices and the export-import status of the country relative to energy resources also gained attention in empirical research. (Richmond and Kaufmann, 2006; He and Richard, 2010; Al-Mulali and Ozturk, 2016) In case when the country is an importer of energy resources and in times of rising energy prices, the stimulus to substitute energy-intensive technologies by renewable energy resources or more environmentally friendly ones, is supposed to be greater. In case of exporting countries, rising global energy prices lead to increased profit and greater output, which, in turn, may lead to higher level of pollution (He and Richard, 2010).

Also empirical research on the EKC hypothesis may be divided for developed and developing countries. The results of the studies are heterogeneous in nature. In some papers, authors find evidence in favor of the inverted U-shaped curve, while in others the N-shaped. E.g., Halicioglu and Ketenci (2016) provided evidence in favor of the existence of EKC only in three out of fifteen transition countries. Onafowora and Owoye (2014) found the N-shaped trajectory in six out of eight studied countries and only in two countries the inverted U-shaped curve was detected. The ambiguity of results may be the consequence of using total pollution as a proxy for environmental degradation, neglecting the differences in the emissions structure in the economy (Stern, 2004).

Although empirical studies, testing the EKC hypothesis, are common today, yet the number of papers, devoted to assessing the role of agriculture in the environmental pollution in the EKC framework are limited. Pretty (2008) stresses the importance of agriculture as an accumulator of carbon when the organic waste is aggregated in the soil, and when it is used as an energy source that substitutes for fossil fuels, thus avoiding carbon. Liu et al. (2017) tested the causality between $\mathrm{CO}_{2}$, renewable energy and agriculture in selected ASEAN-4 countries. The results do not support the inverted U-shaped EKC hypothesis, as well as no causality is found from renewable energy to agriculture, giving evidence to pollutioninducing character of the agriculture. Zafeiriou et al. examined the intertemporal causal relationship between environmental damage from carbon 
emissions released by agriculture per 1000 ha of utilized agriculture area and economic performance in the sector of agriculture as described by net value added per capita. The results of the study, which included Bulgaria, Czech Republic, and Hungary, show that the EKC hypothesis is present in the long run for Bulgaria and Czech Republic while in the short run is validated only for the case of Czech Republic, giving evidence in favor of agriculture being an important factor of environment pollution.

Despite the interest in testing the EKC hypothesis, empirical research of the EKC in Russian case is almost absent. Pao and Tsai (2010), testing the EKC hypothesis for BRIC countries, found that emissions are "output inelastic" and the EKC is not supported. Halicioğlu and Ketenci (2016) and Yang et al. (2017) found support for the EKC in Russia, where the economy-related greenhouse emissions are presented by energy consumption, emissions from industrial process, from animal husbandry and fugitive emissions. Ketenci (2018) also find support for the EKC in Russia, stressing importance of energy consumption, real income, education and urbanization levels for environmental pollution in Russia. Also mixed results for Russian case are found by Mihalischev and Raskina (2015), Rudenko (2018) on macro, regional and citylevels. The results of testing the EKC hypothesis are controversial, even when Russia is included in the panel of BRIC countries. The results of Pao and Tsai (2010) speak in favor of the EKC in Russia, while the results of Chang (2015) speak in favor of the U-shaped curve, which is controversial to conventional results.

Unfortunately, none of the studies, devoted to the Russian case, incorporate agriculture as an important variable and determinant of the environmental pollution. Given the above, this study is aimed to fill this gap in the literature.

\section{Materials and methods}

\section{Research methodology}

Given the heterogeneity of the obtained results on the EKC hypothesis, discussed in the previous section, we aim to fill the gap by enquiring into the nature of the relationship between $\mathrm{CO}_{2}$ emission and agriculture as a share of GDP in the EKC framework. Following methodology for the Russian case, proposed by Ketenci (2018), the basic EKC hypothesis then can be presented as follows: $c_{t}=\beta_{0}+\beta_{1} e_{t}+\beta_{2} i_{t}+\beta 3 i_{t}^{2}+\beta_{4} a_{t}+\varepsilon_{t}$

where $c_{t}$ represents $\mathrm{CO}_{2}$ emission per capita in the sampled country; $e_{t}$ is commercial energy use per capita; $i_{t}$ is the real income, measured as national GDP per capita; $i_{t}^{2}$ represents the square of per capita income; $a_{t}$ is the agriculture, measured as its share in GDP.

Then we transform linear specification of the model into log-linear specification. The log-linear specification provides more appropriate and efficient results compared to simple linear functional form of the model (Cameron, 1994). Moreover, logarithmic form of variables gives direct elasticities for interpretations. Therefore, we specify the estimated equation in log-linear form:

$L c_{t}=\beta_{1}+\beta_{e t} L e_{t}+\beta_{i t} L i_{t}+\beta_{i_{t}{ }^{2}} L i_{t}{ }^{2}+\beta_{a_{t}} L a_{t}+\mu_{t}$

The theoretical foundation of the EKC hypothesis states that the energy consumption is the primary source of shifts and changes in emissions. Then, it is expected the regression coefficient $\beta_{\text {et }}$ to have a positive sign (Suri and Chapman, 1998). Also the EKC hypothesis states that $\beta_{i t}$ is positive, while $\beta_{i_{t}}{ }^{2}$ is negative in sign, demonstrating a rise in $\mathrm{CO}_{2}$ emissions goes alongside the economic growth till the certain threshold, after achieving of which, the emission declines due to technological changes, leading to increasing environment quality. Coefficient $\beta_{a_{t}}$ may be positive or negative, depending on the current stage of development of the national economy, political and institutional factors, stimulating introduction of environmentfriendly technologies in the economy and agricultural sector particularly. On the one hand, increasing share of agriculture in Russian GDP is expected to negatively affect the environmental quality due to its energy intensive production cycle. On the other hand, the results may be opposite as well, given the introduction of environmentfriendly technologies in the agricultural sector.

In this study we employ the ARDL bound test approach, which allows for I(0), I(1) or fractionally integrated variables. Yet, if the variables are I(2) integrated, the use of this methodology is unacceptable. That is why the first step of this study is to check the stationarity of the sampled variables and determine whether it us achieved without second differencing procedure. For this we employ four alternative unit root tests: the Augmented Dickey-Fuller (ADF) test (Dickey 
and Fuller, 1979), the Dickey-Fuller generalized least squares (DF-GLS) test proposed by Elliot et al. (1996), the Phillips and Perron (1988) PP test and the KPSS (Kwiatkowski et al., 1992) test. The null hypothesis of the ADF, DF-GLS and PP tests states that the there exists a unit root, while the alternative hypothesis states that the series are generated by a stationary process. The null hypothesis of the KPSS test is of reverse nature - it states that the series are stationary, while the alternative hypothesis states that the unit root is present.

After determining the stationary character of the series, the study employs the bounds testing approach, proposed by Pesaran et al. (2001) for cases with low span of data. The bounds testing approach is also known as the autoregressive distributed lag model (ARDL), which has some important advantages over the Johansen cointegration test (Pesaran and Shin, 1999). The most important advantage of the ARDL approach is that the ARDL approach can be used regardless the integration order of variables I(0), I(1) or both. Yet, the approach is invalid in case when the I(2) integrated variables are present. Also of great importance is that the ARDL approach allows differences in lags of the sampled variables in the data generating process. Endogenuity problem is absent in the ARDL approach because it also corrects for residual serial correlation. Also the ARDL approach allows to estimate shortrun parameters by the means of the error correction model (ECM) adjustments.

The first step in the ARDL procedure is the determining the co-integration existence between the sampled variables. The bounds test examines long-run relationships, where the ARDL framework of the model (Equation 2) is expressed in Equation 3:

$$
\begin{aligned}
\Delta \ln c_{t} & =\gamma_{1}+\sum_{i=1}^{p} \gamma_{i} \Delta \ln c_{2 t-i}+\sum_{j=0}^{q} \gamma_{j} \Delta \ln e_{t-j} \\
& +\sum_{k=o}^{m} \gamma_{k} \Delta \ln i_{t-k}+\sum_{l=0}^{n} \gamma_{l} \Delta \ln i_{t-l}{ }^{2} \\
& +\sum_{s=0}^{o} \gamma_{5} \Delta \ln a_{t-s}+\gamma_{c_{t-1}} \ln c_{t-1} \\
& +\gamma_{e_{t-1}} \ln e_{t-1}+\gamma_{i_{t-1}} \ln i_{t-1} \\
& +\gamma_{i_{t-1}} \ln _{t-1}{ }^{2}+\gamma_{a_{t-1}} \ln a_{t-1}+\mu_{t}
\end{aligned}
$$

where $\gamma_{c_{t-1}}=\gamma_{e_{t-1}}=\gamma_{i_{t-1}}=\gamma_{i_{t-1}{ }^{2}}=\gamma_{a_{t-1}}=0$. represent short-term coefficients of the sampled variables in the logarithmic forms and $\gamma_{i}, \gamma_{j}, \gamma_{k}, \gamma_{p}, \gamma_{s}$ represent the long-term coefficients of the sampled variables in the logarithmic forms. Presence or absence of the relationship is tested by employing the joint $F$ or statistics of the Wald test. The null hypothesis of nocointegration in the model is $\gamma_{c_{t-1}}=\gamma_{e_{t-1}}=\gamma_{i_{t-1}}=\gamma_{i_{t-1}{ }^{2}}=\gamma_{a_{t-1}}=0$.

The alternative hypothesis of cointegration between the variables is $\gamma_{c_{t-1}} \neq \gamma_{e_{t-1}} \neq \gamma_{i_{t-1}}$ $\neq \gamma_{i_{t-1}} \neq \gamma_{a_{t-1}} \neq 0$. To test the significance of the obtained results, the critical values for the bound test, reported in Pesaran et al. (2001) are used. The critical bounds are set as if the variables are of $\mathrm{I}(0)$ and are of $\mathrm{I}(1)$. If the F-statistics is above the upper bound of the critical values, the null hypothesis is rejected. If the F-statistics is below the lower critical bound, the null hypothesis is accepted. If the F-statistics is between the bounds, the results of the test are inconclusive.

In case of the presence of co-integration between the variables, the next stage is the estimation of the ECM of the following type (Equation 3):

$$
\begin{aligned}
\Delta l n c_{t} & =\theta_{1}+\sum_{i=0}^{p} \theta_{2} \Delta l n c_{t-i}+\sum_{k=0}^{q} \theta_{3} \Delta l n e_{t-k} \\
& +\sum_{i=o}^{r} \theta_{3} \Delta \ln i_{t-r}+\sum_{i=0}^{s} \theta_{4} \Delta \ln i_{t-s}{ }^{2} \\
& +\sum_{i=0}^{l} \theta_{5} \Delta \ln a_{t-l}+\delta_{1} E C M_{t-1}+\varphi_{t}
\end{aligned}
$$

where $E C M_{t-1}$ represents the error correction term and $\delta_{1}$ is the coefficient, estimating the speed of variables adjustment towards the equilibrium. This coefficient has to be statistically significant and negative in sign. The existence of an ECT implies the changes in dependent variable. These changes are a function of both the levels of disequilibrium in the cointegration relationship and the changes in the other explanatory variables. This indicates the deviation in dependent variable from short span of time to long-run equilibrium path (Masih and Masih, 1997). The goodness of fit for ARDL model is checked through stability tests such as cumulative sum of recursive residuals (CUSUM) and cumulative sum of squares of recursive residuals (CUSUMSQ).

\section{Data}

The study aims to test the short and longrun relationships between carbon emission and their determinants in the framework of the EKC hypothesis. The variables include energy consumption, real income and agriculture 
in the Russian case for the period 1990-2016. The study employs annual data. The data are collected from the World Bank's World Development Indicators database and Russian statistical database when and where needed.

Carbon emissions are measured by $\mathrm{CO}_{2}$ emissions per capita in the sampled country, metric tonnes; energy consumption is measured by commercial energy use in Russia per capita, $\mathrm{kg}$ of oil equivalent; real income is represented by Russian GDP per capita, constant 2010 US dollars; agriculture is measured as a percentage share of value added by agricultural sector in Russian GDP. All variables then are transformed in natural logarithms.

\section{Results and discussion}

Descriptive statistics for the sampled variables are presented in Table 1. Carbon emissions in Russia amounts 11.77 metric tonnes per capita for the period from 1990 to 2016. Commercial energy consumption is $4711.48 \mathrm{~kg}$ of oil equivalent per capita. The average share of agriculture in Russian GDP is $5.67 \%$ with the tendency to decrease from $15 \%$ to $3 \%$ in the long-run. Yet, beginning from 2011 statistics show a rise in the share of agriculture in Russian GDP up to about $5 \%$.

The study is based on the usage of Russian data for the sampled variables for the period 1990-
2016 and aimed to explore the long and short-run relationships between $\mathrm{CO}_{2}$ emissions and variables which have the potential to affect the changes in the environmental pollution process under the EKC hypothesis. These include energy consumption, real income and agriculture. For the purposes of the study the ARDL bounds test approach is employed, that assumes the use of the variables with different order of integration, except integration of order above I(1). The first goal, then, should be the investigation of the order of sampled variables integration, achieving which supposes testing the variables for stationarity in order to determine if the ARDL approach suits the study. We employ four different unit root tests, including the ADF, the DF-GLS, the PP and the KPSS tests. The results of testing the variables for stationarity are presented in Table 2.

The results of the tests for stationarity show that all the sampled variables of the study are generated by a stationary process. Given the results of the different unit root tests, we can assume that the variables in the study are integrated of the order 0 or 1 and none is integrated of the order above 1 .

Given that the variables of the study are not integrated of the order 2 we can proceed with the ARDL cointegration approach. The first step in the ARDL co-integration analysis requires identification of the optimal lag length

\begin{tabular}{|l|c|c|c|c|c|}
\hline Variable & Mean & Max. & Min. & St. dev. & Obs. \\
\hline$c$ & 11.77003 & 16.08000 & 10.12730 & 1.339353 & 27 \\
\hline$e$ & 4711.481 & 5928.661 & 3981.502 & 497.5094 & 27 \\
\hline$i$ & 8707.101 & 11803.71 & 5505.628 & 2226.278 & 27 \\
\hline$a$ & 5.675496 & 15.46104 & 3.160549 & 2.900097 & 27 \\
\hline
\end{tabular}

Note: Max. is the abbreviation for maximum value of a variable, Min. is for the minimum value, St. dev. is referred to a standard deviation, Obs. is the number of observations, $\mathrm{c}$ is the abbreviation for carbon emission, e is for energy consumption, $\mathrm{r}$ is for real income and $\mathrm{a}$ is for agriculture share of value added (as a \% of GDP).

Source: own calculations

Table 1: Descriptive statistics.

\begin{tabular}{|l|c|c|c|c|}
\hline Variable & ADF & DF-GLS & PP & KPSS \\
\hline$c$ & $-3.852911^{*}$ & $-3.003408^{*}$ & $-3.655386^{* *}$ & 0.174587 \\
\hline$e$ & $-3.207594^{* *}$ & $-3.280949 *$ & $-3.216722^{* *}$ & 0.369353 \\
\hline$i$ & $-3.687551^{* *}$ & $-2.261857^{* *}$ & $-2.358914^{* *}$ & 0.308785 \\
\hline$a$ & $-3.324449 * *$ & $-5.386401 *$ & $-3.573855^{* *}$ & 0.712689 \\
\hline
\end{tabular}

Note: The null hypothesis of ADF, DF-GLS and PP unit root tests is the presence of the unit root. The null hypothesis of the KPSS test is the stationarity of an estimated variable. * and ** denote the rejection of the null hypothesis at the $1 \%$ and $5 \%$ significance levels, respectively.

Source: own calculations 
under the unrestricted vector autoregression. For these purposes we use the Schwarz Criterion (SC), the Akaike Information Criterion (AIC) and the Hannan-Quinn Information criterion (HQ). All the information criteria stand for the lag length of 2 years (Table 3 ).

\begin{tabular}{|l|c|c|c|}
\hline Lag & AIC & SC & HQ \\
\hline 0 & -10.41324 & -10.21822 & -10.35915 \\
\hline 1 & -15.17782 & -13.81442 & -14.90737 \\
\hline 2 & $-15.56960^{*}$ & $-14.20272^{*}$ & $-15.08278^{*}$ \\
\hline
\end{tabular}

Note: * indicates lag order selected by the criterion AIC - Akaike information criterion, SC - Schwarz information criterion, HQ: Hannan-Quinn information criterion.

Source: own calculations

Table 3. Results of optimal lag length selection.

Then we can proceed to determining the long-run relationships between the variables of the study. To check the variables on the existence of the long-run relationship we employ the bound F-test for Equation 2. The results of the bounds test for the estimated equation are presented in Table 4 .

The estimated equation includes both dependent and independent variables. Dependent variables include energy consumption, real income and square of the real income, while agriculture stands as an independent variable. The results of the cointegration F-test show that the resulting F-statistics are above the upper bound and statistically significant at $10 \%, 5 \%$ and $1 \%$ significance level. The results show that the sampled variables are cointegrated and the long-run relationship between the variables exists in the Russian case. The obtained results are in line with the results of Ketenci (2018).

Given that the sampled variables are cointegrated in the long-run, we can proceed to the next stage, that requires estimation of the long and short-run coefficients. Given that the ARDL model was estimated in the logarithmic form, we can estimate how a shock in $1 \%$ of the explanatory variables affect the control variable both in the long and short run.

The estimates for the short-run relationships are presented in Table 5.

\begin{tabular}{|l|c|c|}
\hline Regressor & Coefficient & t-statistics \\
\hline$\Delta \ln e$ & 0.894 & $7.674^{*}$ \\
\hline$\Delta \ln i$ & 0.009 & $1.908^{*}$ \\
\hline$\Delta \ln i^{2}$ & -0.014 & $-2.671^{*}$ \\
\hline$\Delta \ln a$ & 0.082 & $2.177^{*}$ \\
\hline$E C M_{t-1}$ & -0.728 & $-5.726^{*}$ \\
\hline \multicolumn{2}{|c|}{ Diagnostic test statistics } \\
\hline$R^{2}$ & \multicolumn{2}{|c|}{0.934} \\
\hline DW-statistic & 2.47 \\
\hline F-statistic & \multicolumn{2}{|c|}{4.69} \\
\hline RSS & 0.01 \\
\hline
\end{tabular}

Note: * and ** denote the rejection of the null hypothesis at the $1 \%$ and $5 \%$ significance levels respectively. $\beta$ column reports estimated coefficients.

Source: own calculations

Table 5: ARDL short-run results.

As can be seen from the results of the short-run relationship estimation, the error correction term is negative in sign and statistically significant at $1 \%$ level. This result confirms the presence of the co-integration. The value of the ECM coefficient is 0.728 , that allows to assume that in Russia about $73 \%$ of the $\mathrm{CO}_{2}$ emissions disequilibrium in the short-run is rectified. The diagnostic test results imply the acceptable fit of the model, given the appropriate $\mathrm{R}^{2}$ and significant F-statistic. Durbin-Watson statistics coefficient shows that the error terms are not correlated. The absence of autocorrelation in the disturbance of the error term is proved by the Breusch-Godfrey test. The normality criterion of the model is also met.

Given the results of the short-run estimates, we obtain evidence in favor of the EKC hypothesis in Russia. Particularly, the energy consumption and the real income have a small yet positive effect on the $\mathrm{CO}_{2}$ emissions during the sampled

\begin{tabular}{|l|c|c|c|c|l|l|}
\hline F-statistics & $90 \% \mathrm{LB}$ & $90 \% \mathrm{UB}$ & $95 \% \mathrm{LB}$ & $95 \% \mathrm{UB}$ & $99 \% \mathrm{LB}$ & $99 \% \mathrm{UB}$ \\
\hline 6.46 & $3.47 *$ & $4.45^{*}$ & $4.01 *$ & $5.07 *$ & 5.17 & 6.36 \\
\hline
\end{tabular}

Note: Null hypothesis of the ARDL bounds test is: No long-run relationship exists. LB - low bound, UB - upper bound. If the F test statistic falls between lower and upper bounds the result is inconclusive. If it is below lower bound, the null hypothesis cannot be rejected. If the test statistics is above upper bound, the null hypothesis of no co-integration is rejected $(*)$. Source: own calculations 
period. E.g., a $1 \%$ rise in energy consumption increases $\mathrm{CO}_{2}$ emissions by $0.89 \%$. The signs of the coefficients of GDP and GDP square also speak in favor of the EKC hypothesis in Russia at $1 \%$ significance level: a $1 \%$ rise in GDP increases $\mathrm{CO}_{2}$ emissions by $0.01 \%$. The square of the real income coefficient has a negative sign, that speaks in favor of the EKC hypothesis in Russia, confirms the results of Ketenci (2018) and supports the results of Halicioglu and Ketenci (2016) as well as Yang et al. (2017) and Chang (2015).

Another finding indicates that agriculture plays a statistically significant role in environmental pollution in Russia, given the positive sign of the $\beta$ coefficient, that confirms the relative importance of agricultural sector as a short-run source of environmental pollution in Russia. A $1 \%$ rise of agriculture as a share of the national GDP increases $\mathrm{CO}_{2}$ emissions in Russia by almost $0.1 \%$. The result is relatively small yet statistically significant, which gives us the right to accept the hypothesis of agriculture being a source of environmental pollution in Russia.

The estimates of the long-run relationship between the studied variables are presented in Table 6 .

\begin{tabular}{|l|c|c|}
\hline Regressor & Coefficient & t-statistics \\
\hline$\Delta \ln e$ & 0.923 & $10.263^{*}$ \\
\hline$\Delta \ln i$ & 0.008 & $1.732^{*}$ \\
\hline$\Delta \ln i^{2}$ & -0.017 & $-2.844^{*}$ \\
\hline$\Delta \ln a$ & 0.091 & $2.351^{*}$ \\
\hline$E C M_{t-1}$ & 6.178 & $5.806^{*}$ \\
\hline \multicolumn{3}{|c|}{ Diagnostic test statistics } \\
\hline \multicolumn{3}{|c|}{$t$-statistics } \\
\hline$\chi_{S C}^{2}$ & 1.85 & 0 -value \\
\hline$\chi_{F F}^{2}$ & 0.12 & 0.213 \\
\hline$\chi_{N}^{2}$ & 3.49 & 0.893 \\
\hline$\chi_{H}^{2}$ & 0.89 & 0.9294 \\
\hline
\end{tabular}

Note: * and ** denote the rejection of the null hypothesis at the $1 \%$ and $5 \%$ significance levels respectively. $\beta$ column reports estimated coefficients. $\chi_{S C}^{2}, \chi_{F F}^{2}, \chi^{2}{ }_{N}, \chi_{H}^{2}$ present the BreuschGodfrey serial correlation LM test, the Ramsey RESET test of functional form misspecification, the Jarque-Bera normality test and the Breusch-Pagan-Godfrey heteroscedasticity test, respectively.

Source: own calculations

Table 6: ARDL long-run results.

As can be seen from the results, presented in Table 6, the estimates of the ARDL model are found to be statistically significant. The long-run estimates, as the short-run ones, of the energy consumption, real income and agriculture positively affect the $\mathrm{CO}_{2}$ emissions in Russia. The impact of the energy consumption is stronger than that of the GDP, which supports the energy-induced pollution hypothesis. An increase in energy consumption per capita in Russia by $1 \%$ leads to an increase in the $\mathrm{CO}_{2}$ emissions per capita by $0.923 \%$, while an increase of the real income in $1 \%$ leads to $0.01 \%$ of environmental pollution. A $1 \%$ increase in agriculture as a share of GDP leads to only almost $0.01 \%$ increase in the $\mathrm{CO}_{2}$ emissions in Russia.

These results need interpretation. The presence of the impact of energy consumption on $\mathrm{CO}_{2}$ emissions in Russia is quite logical, given low energy efficiency and high energy intensity of the Russian economy. Second, the low impact of the GDP on environmental pollution is achieved because of the structure of the Russian economy, where energy intensive and "toxic" sectors (such as oil and gas industry, agriculture and metal industry) account for less than $50 \%$ of the GDP: the share of agriculture being around $5 \%$, the share of oil and gas industry being around $10 \%$ on average. Then the low impact of the $\beta$-coefficient for the Russian GDP becomes quite logical. The impact of the agriculture as a source of the environmental pollution is also relatively small (almost $0.1 \%$ ) given the national authorities' policies, stimulating the use of environment-friendly technologies, e.g. reducing emissions of $\mathrm{NH}_{3}, \mathrm{CO}, \mathrm{CO}_{2}, \mathrm{SO}_{2}, \mathrm{CH}_{4}, \mathrm{~N}_{2} \mathrm{O}, \mathrm{SF}$, as well as the negative impact of benzene and wood dust from agrarian enterprises.

Given the above results, the EKC hypothesis finds support: the positive sign of the real income is changed by the negative sign of the squared real income, showing an inverted U-shaped relationship between $\mathrm{CO}_{2}$ emissions and the real income in the Russian case, as well as supporting the relative importance of the agricultural sector as a source of environmental pollution and necessity to increase the level of environment-friendly technologies used in agriculture.

Another important aspect of the long-run estimates is the magnitude of the positive and negative impacts of the real income and the square of the real income on the $\mathrm{CO}_{2}$ emissions. The magnitude of the positive impact of the GDP on $\mathrm{CO}_{2}$ emissions in Russia is less than the negative impact of the squared GDP per capita. This implies that the environmental improvement takes its place in the Russian economy after achieving a certain threshold, compared to the initial environment degradation process. This result is confirmed 
by the World Bank (2018), according to which $\mathrm{CO}_{2}$ emissions, measured as $\mathrm{kg}$ per 2010 US dollars of GDP, have declined in Russia from 1.839 in 1998 to 0.999 in 2014.

Another important test to explore the relationships between the sampled variables is the pairwise Granger causality test. The results of the causality test are presented in Table 7.

\begin{tabular}{|l|c|c|}
\hline Null hypothesis & F-statistic & p-value \\
\hline $\ln e$ does not Granger cause $\ln c$ & 3.076 & 0.001 \\
\hline $\ln c$ does not Granger cause $\ln e$ & 8.962 & 0.004 \\
\hline $\ln i$ does not Granger cause $\ln c$ & 5.901 & 0.022 \\
\hline $\ln c$ does not Granger cause $\ln i$ & 4.093 & 0.049 \\
\hline $\ln i^{2}$ does not Granger cause $\ln c$ & 5.084 & 0.002 \\
\hline $\ln c$ does not Granger cause $\ln i^{2}$ & 4.212 & 0.052 \\
\hline $\ln a$ does not Granger cause $\ln c$ & 7.209 & 0.005 \\
\hline $\ln c$ does not Granger cause $\ln a$ & 0.953 & 0.431 \\
\hline
\end{tabular}

Source: own calculations

Table 7: Pairwise granger causality test.

According to the results of the pairwise Granger causality test, the unidirectional causality running from agriculture to the $\mathrm{CO}_{2}$ emissions in Russia exists. Moreover, the bidirectional causality between $\mathrm{CO}_{2}$ emissions and energy consumption, real income and real income squared has been revealed.

The last step in the ARDL approach is estimating the stability of the model. For this purpose, we employ the cumulative (CUSUM) and the cumulative sum of squares (CUSUMSQ) stability tests, proposed by Brown et al. (1975). The results of the CUSUM and CUSUMSQ tests are presented in Figures 1 and 2.

As can be seen from Figures 1 and 2, the plots of the CUSUM and the CUSUMSQ statistics are located within the $5 \%$ significance critical bounds, which proves the stability of the developed model.

\section{Conclusion}

This study explores the relationship between carbon dioxide emissions and their main determinants, which include real income and energy consumption in Russia, employing data for the period 1990-2016. The hypothesis of agriculture being an important determinant of environmental quality in Russia is also tested. For estimating the short-run and longrun relationships the ARDL bounds test is employed in this study. To check the causal relationship, the pairwise Granger causality test is employed.

The results of the cointegration F-test show that the resulting F-statistics are above the upper bound and statistically significant at $10 \%, 5 \%$ and $1 \%$ significance level. The results show that the sampled variables are cointegrated and the longrun relationship between $\mathrm{CO}_{2}$ emissions, energy consumption, real income and agriculture exists in the Russian case. According to the results of the short-run relationship estimation, the value of the ECM coefficient is 0.728 , that allows to assume that in Russia about $73 \%$ of the $\mathrm{CO}_{2}$ emissions disequilibrium in the short-run is rectified, which also gives evidence in favor of the EKC hypothesis in Russia. Another empirical finding is that agriculture plays a small yet statistically significant role in environmental pollution in Russia, that confirms the importance of agricultural sector as a short-run source of environmental pollution in Russia. The long-run estimates, as the shortrun ones, of the energy consumption, real income and agriculture positively affect $\mathrm{CO}_{2}$ emissions
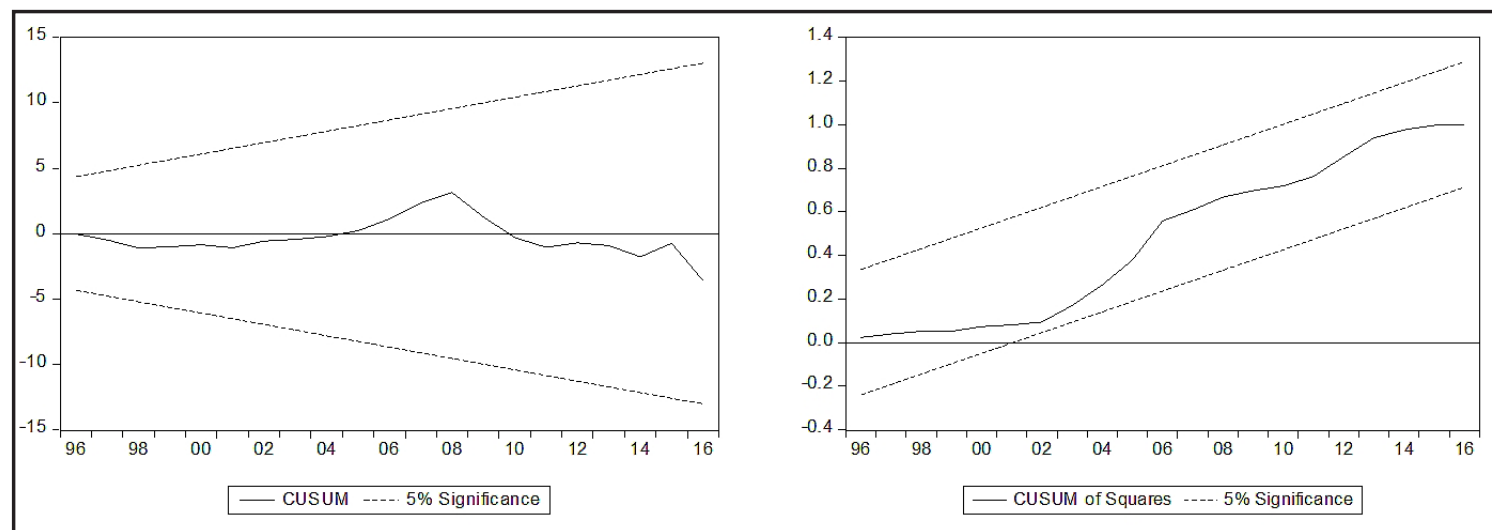

Source: own calculations

Figures 1 and 2: Results of the stability tests. 
in Russia. E.g., an increase in energy consumption per capita in Russia by $1 \%$ leads to an increase in the $\mathrm{CO}_{2}$ emissions per capita by $0.923 \%$. An increase of the real income in $1 \%$ causes only $0.01 \%$ of environmental pollution. A $1 \%$ increase in agriculture as a share of GDP leads to an almost $0.1 \%$ increase in the $\mathrm{CO}_{2}$ emissions in Russia. The results of the pairwise Granger causality test also confirm the unidirectional causality running from agriculture to the $\mathrm{CO}_{2}$ emissions in Russia.

Corresponding authors

Dr. Dmitry Burakov

Department of Banks, Monetary Circulation and Credit

Moscow State Institute of International Relations (MGIMO-University)

Prospect Vernadskog 76, 119454 Moscow, Russia

Email:dbur89@yandex.ru

\section{References}

[1] Akbostanci, E., Asik, S. and Tunc, G. I. (2009) "The relationship between income and environment in Turkey: is there an environmental Kuznet curve?", Energy Policy, Vol. 37, No. 3, pp. 861-867. ISSN 0301-4215. DOI 10.1016/j.enpol.2008.09.088.

[2] Acaravci, A. and Ozturk, I. (2010) "On the relationship between energy consumption, $\mathrm{CO}_{2}$ emissions and economic growth in Europe“, Energy, Vol. 35, No. 12, pp. 5412-5420. ISSN 0360-5442. DOI 10.1016/j.energy.2010.07.009.

[3] Alam, M. J., Begum, I. A., Buysse, J. and Huylenbroeck, G.V. (2012) "Energy consumption, carbon emissions and economic growth nexus in Bangladesh: Cointegration and dynamic causality analysis“, Energy Policy, Vol. 45, pp. 217-225. ISSN 0301-4215. DOI 10.1016/j.enpol.2012.02.022

[4] Al-Mulali, U. and Özturk, I. (2016) "The investigation of environmental Kuznets curve hypothesis in the advanced economies: The role of energy prices“, Renewable \& Sustainable Energy Reviews, Vol. 54, pp. 1622-1631. ISSN 1364-0321. DOI 10.1016/j.rser.2015.10.131.

[5] Benavides, M., Ovalle, K., Torres, C. and Vinces, T. (2017) "Economic growth, renewable energy and methane emissions: Is there an environmental Kuznets Curve in Austria?", International Journal of Energy Economics and Policy, Vol. 7, No. 1, pp. 259-267. ISSN 2146-4553.

[6] Brown, R. L., Durbin, J. and Evans, J. M. (1975) "Techniques for testing the constancy of regression relations over time", Journal of the Royal Statistical Society. Series B. Methodological, Vol. 37, pp. 149-163. ISSN 1467-9868. DOI 10.1111/j.2517-6161.1975.tb01532.x.

[7] Cameron, S. (1994) "A review of the econometric evidence on the effects of capital punishment." Journal of Socio-Economics, Vol. 23, No. 1-2, pp. 197-214. ISSN 1053-5357. DOI 10.1016/1053-5357(94)90027-2.

[8] Chang, M.-C. (2015) "Room for improvement in low carbon economies of G7 and BRICS countries based on the analysis of energy efficiency and environmental Kuznets curves“, Journal of Cleaner Production, Vol. 99, pp. 140-151. ISSN 0959-6526. DOI 10.1016/j.jclepro.2015.03.002.

[9] Chow, G. C. (1960) "Test of equality between sets of coefficients in two linear regressions", Econometrica, Vol. 28, No. 3, p. 591-605. ISSN 1468-0262. DOI 10.2307/1910133.

[10] Dagher, L. and Yacoubian, T. (2012) "The causal relationship between energy consumption and economic growth in Lebanon“, Energy Policy, Vol. 50, pp. 795-801. ISSN 0301-4215. DOI 10.1016/j.enpol.2012.08.034. 
[11] Dickey, D. A. and Fuller, W. A. (1979) "Distribution of the estimators for autoregressive time series with a unit root", Journal of the American Statistical Association, Vol. 74, No. 366a, pp. 427-431. ISSN 1537274X. DOI 10.1080/01621459.1979.10482531.

[12] El-Aasar, K. M. and Hanafy, S. A. (2018) "Investigating the Environmental Kuznets Curve Hypothesis in Egypt: The Role of Renewable Energy and Trade in Mitigating GHGs", International Journal of Energy Economics and Policy, Vol. 8, No. 3, pp. 177-184. ISSN 2146-4553.

[13] Elliot, G., Rothenberg, T. and Stock, J. (1996) "Efficient tests for an autoregressive unit root", Econometrica, Vol. 64, No. 4, pp. 813-836. ISSN 1468-0262. DOI 10.2307/2171846.

[14] Grossman, G. M. and Krueger, A. B. (1995) "Economic growth and the environment", The Quarterly Journal of Economics, Vol. 112, No. 2, pp. 353-378. ISSN 0033-5533. DOI 10.2307/2118443.

[15] Halicioglu, F. (2009) "An econometric study of $\mathrm{CO}_{2}$ emissions, energy consumption, income and foreign trade in Turkey", Energy Policy, Vol. 37, No. 3, pp. 1156-1164. ISSN 0301-4215. DOI 10.1016/j.enpol.2008.11.012.

[16] Halicioglu, F. and Ketenci, N. (2016) "The impact of international trade on environmental quality: The case of transition countries”, Energy, Vol. 109, pp. 1130-1138. ISSN 0360-5442. DOI 10.1016/j.energy.2016.05.013.

[17] He, J. and Richard, P. (2010) "Environmental Kuznets curve for $\mathrm{CO}_{2}$ in Canada", Ecological Economics, Vol. 69, No. 5, pp. 1083-1093. ISSN 0921-8009. DOI 10.1016/j.ecolecon.2009.11.030

[18] Heil, M. T., Selden, T. M. (1999) "Panel stationarity with structural breaks: carbon emissions and GDP", Applied Economics Letters, Vol. 6, pp. 223-225. ISSN 1466-4291. DOI: $10.1080 / 135048599353384$.

[19] Ketenci, N. (2018) "The environmental Kuznets curve in the case of Russia", Russian Journal of Economics, Vol. 4, No. 3, pp. 249-265. ISSN 2405-4739. DOI 10.3897/j.ruje.4.28482

[20] Ivanova, V. I. and Vertkina, D. (2017) “Environmental Kuznets curve: Russian cities' case”, In Yasin, Y. G. (Ed.), XVII International science conference on economic and social development problems, Moscow: National Research University Higher School of Economics, pp. 156-165.

[21] Kuznets, S. (1955) "Economic growth and income inequality", American Economic Review, Vol. 45, No. 1, pp. 1-28. ISSN 0002-8282.

[22] Kwiatkowski, D., Phillips, P., Schmidt, P. and Shin, Y. (1992) "Testing the null hypothesis of stationarity against the alternative of a unit root", Journal of Econometrics, Vol. 54, No. 1-3, pp. 159-178. ISSN 0304-4076. DOI 10.1016/0304-4076(92)90104-Y.

[23] Liu, X., Zhang, S. and Bae, J. (2017) "The impact of renewable energy and agriculture on carbon dioxide emissions: Investigating the environmental Kuznets curve in four selected ASEAN countries", Journal of Cleaner Production, Vol. 164, pp. 1239-1247. ISSN 0959-6526. DOI 10.1016/j.jclepro.2017.07.086.

[24] Masih, A. M. M. and Masih, R. (1997) "On temporal causal relationship between energy consumption, real income and prices: some new evidence from Asian energy dependent NICs based on a multivariate cointegration vector error correction approach", Journal of Policy Modeling, Vol. 19, pp. 417-440. ISSN 0161-8938. DOI 10.1016/S0161-8938(96)00063-4.

[25] Mihalischev S. and Raskina, Y. (2015) "Environmental Kuznets Curve: The Case of Russia", EUSP Department of Economics Working Paper Series Ec-03/15, European University at St. Petersburg, Department of Economics.

[26] Narayan, P. K. and Narayan, S. (2010) "Carbon dioxide emissions and economic growth: Panel data evidence from developing countries”, Energy Policy, Vol. 38, No. 1, pp. 661-666. ISSN 0301-4215. DOI 10.1016/j.enpol.2009.09.005. 
[27] Onafowora, O. A. and Owoye, O. (2014) "Bounds testing approach to analysis of the environment Kuznets curve hypothesis", Energy Economics, Vol. 44, pp. 47-62. ISSN 0140-9883. DOI 10.1016/j.eneco.2014.03.025.

[28] Pao, H. T. and Tsai, C. M. (2010) " $\mathrm{CO}_{2}$ emissions, energy consumption and economic growth in BRIC Countries", Energy Policy, Vol. 38, No. 12, pp. 7850-7860. ISSN 0301-4215. DOI 10.1016/j.enpol.2010.08.045.

[29] Poudel, B. N., Paudel, K. P. and Bhattarai, K. (2009) "Searching for an environmental Kuznets curve in carbon dioxide pollutant in Latin American countries", Journal of Agricultural and Applied Economics, Vol. 41, No. 1, pp. 13-27. ISSN 1074-0708. DOI 10.1017/S1074070800002522.

[30] Pesaran, M. H. and Shin, Y. (1999) “An autoregressive distributed lag modeling approach to cointegration analysis", In Strom S. (ed.) "Econometrics and Economic Theory in the $20^{\text {th }}$ Century", Cambridge University Press, Cambridge, pp. 371-413.

[31] Pesaran, M. H., Shin, Y. and Smith, R. (2001) "Bounds testing approaches to the analysis of level relationships", Journal of Applied Econometrics, Vol. 16, No. pp. 289-326. ISSN 1099-1255. DOI 10.1002/jae.616.

[32] Phillips, P. C. and Perron, P. (1988) "Testing for a unit root in time series regression", Biometrika, Vol. 75, No. 2, pp. 335-346. ISSN 0006-3444. DOI 10.1093/biomet/75.2.335.

[33] Pretty, J. (2008) “Agricultural sustainability: concepts, principles and evidence”, Philosophical Transactions of the Royal Society B: Biological Sciences, Vol. 363, pp. 447-465. ISSN 1471-2970. DOI 10.1098/rstb.2007.2163.

[34] Rabbi, F., Akbar, D. and Kabir, S. M. Z. (2015) "Environment Kuznets curve for carbon emissions: a cointegration analysis for Bangladesh", International Journal of Energy Economics and Policy, Vol. 5, No. 1, pp. 45-53. ISSN 2146-4553.

[35] Richmond, A. K. and Kaufmann, R. K. (2006) "Is there a turning point in the relationship between income and energy use and/or carbon emissions?", Ecological Economics, Vol. 56, No. 2., pp. 176-189. ISSN 0921-8009. DOI 10.1016/j.ecolecon.2005.01.011.

[36] Rudenko, D. (2018) "Environment and economic growth in the Russian Arctic", International Journal of Global Environmental Issues, Vol. 17, No. 2/3, pp. 163-174. ISSN 1741-5136. DOI 10.1504/IJGENVI.2018.10012372.

[37] Saboori, B., Sulaiman, J. (2013) "Environmental degradation, economic growth and energy consumption: evidence of the Environmental Kuznets Curve in Malaysia”, Energy Policy, Vol. 60, pp. 892-905. ISSN 0301-4215. DOI 10.1016/j.enpol.2013.05.099

[38] Shahbaz, M., Ozturk, I., Afza, T. and Ali, A. (2013) "Revisiting the Environmental Kuznets Curve in a global economy", Renewable and Sustainable Energy Reviews, Vol. 25, pp. 494-502. ISSN 1364-0321. DOI 10.1016/j.rser.2013.05.021.

[39] Shahbaz, M., Dube, S., Ozturk, I. and Jalil, A. (2015) "Testing the Environmental Kuznets Curve Hypothesis in Portugal", International Journal of Energy Economics and Policy, Vol. 5, No. 2, pp. 475-481. ISSN 2146-4553.

[40] Soytas, U. and Sari, R. (2009) "Energy consumption, economic growth, and carbon emissions: challenges faced by an EU candidate member", Ecological Economics, Vol. 68, pp. 1667-1675. ISSN 0921-8009. DOI 10.1016/j.ecolecon.2007.06.014.

[41] Stern, D. I. (2004) "The rise and fall of the environmental Kuznets curve", World Development, Vol. 32, No. 8, pp. 1419-1439. ISSN 0305-750X. DOI 10.1016/j.worlddev.2004.03.004.

[42] Suri, V. and Chapman, D. (1998) "Economic growth, trade and energy: Implications for the environmental Kuznets curve", Ecological Economics, Vol. 25, No. 2, pp. 195-208. ISSN 0921-8009. DOI 10.1016/S0921-8009(97)00180-8 
[43] World Bank (2018) "World Development Indicators". [Online]. Available: http://databank. worldbank.org/data/views/re-ports/tableview.aspx?isshared=true [Accessed: 25 Sept. 2018].

[44] Yang, X., Lou, F., Sun, M., Wang, M. and Wang, Y. (2017) "Study of the relationship between greenhouse gas emissions and the economic growth of Russia based on the environmental Kuznets curve", Applied Energy, Vol. 193, pp. 162-173. ISSN 0306-2619. DOI 10.1016/j.apenergy.2017.02.034

[45] Zafeiriou, E., Sofios, S. and Partalidou, X. (2017) "Environmental Kuznets curve for EU agriculture: empirical evidence from new entrant EU countries", Environmental Science and Pollution Research, Vol. 24, No. 18, pp. 15510-15520. ISSN 0944-1344. DOI 10.1007/s11356-017-9090-6. 